\title{
Estimating solid wood properties using Pilodyn and acoustic velocity on standing trees of Norway spruce
}

\author{
Zhi-Qiang Chen • Bo Karlsson • Sven-Olof Lundqvist • \\ María Rosario García Gil • Lars Olsson • Harry X. Wu
}

Received: 25 September 2014 / Accepted: 5 January 2015 /Published online: 30 January 2015

(C) INRA and Springer-Verlag France 2015

\begin{abstract}
- Key message Strong genetic correlations were observed between Pilodyn measurement and wood density, and between acoustic velocity and MFA. Combination of Pilodyn penetration and acoustic velocity measurements from standing trees can provide reliable prediction of stiffness of Norway spruce for breeding selection.

- Context Traditional methods for the estimation of solid wood quality traits of standing tree such as wood density, microfibril angle (MFA), and modulus of elasticity (MOE) are time-consuming and expensive, which render them
\end{abstract}

\footnotetext{
Handling Editor: Jean-Michel Leban

Contribution of the co-authors Zhiqiang Chen's contribution includes field data collection, data analysis, and the writing of the manuscript. Bo Karlsson coordinated field experiment and data collection, and contributed to the writing of the manuscript. María Rosario García Gil coordinated the experiment design and contributed to the writing of the manuscript. Sven-Olof Lundqvist and Lars Olsson conducted SilviScan experiment and initial data analyses, and contributed to the writing of the manuscript. Harry X. Wu initiated the project, designed analytical strategy, and contributed to the writing of the manuscript. All authors read and approved the final manuscript.
}

Z.-Q. Chen • M. R. García Gil • H. X. Wu $(\bowtie)$

Umeå Plant Science Centre, Dept. Forest Genetics and Plant

Physiology, Swedish University of Agricultural Sciences,

SE-90183 Umeå, Sweden

e-mail: harry.wu@slu.se

B. Karlsson

Skogforsk, Ekebo 2250, SE-268 90 Svalöv, Sweden

S.-O. Lundqvist $\cdot$ L. Olsson

INNVENTIA AB, Drottning Kristinas väg 61, SE-114

86 Stockholm, Sweden

H. X. Wu

CSIRO Plant Industry, GPO Box 1600, Canberra ACT 2601,

Australia unsuitable for rapidly screening a large number of trees in tree breeding programs.

- Aim This study aims to evaluate the suitability of using Pilodyn penetration and acoustic velocity (nondestructive evaluation) to assess wood density, MFA, and MOE for Norway spruce.

- Methods Pilodyn penetration and Hitman acoustic velocity, as well as wood density, MFA, and MOE using benchmark SilviScan were measured on 5618 standing trees of 524 openpollinated families in two 21-year-old Norway spruce (Picea abies) progeny trials in southern Sweden.

- Results Strong genetic correlations were observed between Pilodyn measurement and wood density $\left(r_{\mathrm{g}}=-0.96\right)$, and between acoustic velocity and MFA $\left(r_{\mathrm{g}}=-0.94\right)$. Combination of Pilodyn penetration and Hitman acoustic velocity measurements $\left(\mathrm{MOE}_{\left(\mathrm{AV}^{2}+\mathrm{Pilo}\right)}\right)$ obtained from standing trees showed a genetic correlation with benchmark MOE of 0.99. This combined $\mathrm{MOE}_{\left(\mathrm{AV}^{2}+\mathrm{Pilo}\right)}$ had higher selection efficiency for benchmark MOE (92\%) compared to 58-60 \% using acoustic velocity alone and $78 \%$ using Pilodyn penetration alone.

- Conclusion Combination of Pilodyn penetration with Hitman acoustic velocity provided very high selection efficiency for the three most important quality traits for wood mechanical properties in Norway spruce.

Keywords Nondestructive evaluation - Wood density · Microfibril angle $\cdot$ Modulus of elasticity $\cdot$ Norway spruce

\section{Introduction}

Wood density, microfibril angle (MFA), and modulus of elasticity (MOE) are the most important wood mechanical 
properties for structural wood products (Zobel and Van Buijtenen 1989; Zobel and Jett 1995; Hannrup et al. 2004) and are thus the most important traits for tree breeding selection targeting the improvement of structure products (Ivković et al. 2006). Traditional measurements of these traits are, however, either expensive or destructive, particularly for MFA and MOE. Therefore, development of a fast screening method on standing tree is highly desirable (Matheson et al. 2008). Earlier tree breeding programs of conifers only focused on increased growth and resulted in shortening of rotation age for plantation tree species. Such reduction of rotation age has resulted in harvested trees with increased proportion of juvenile wood, which has lower density, higher MFA, and lower MOE. It has consequently caused a reduction in the end-products value (Wu et al. 2008). Therefore, it is important to quantify genetic variation and genetic correlation between growth traits and wood quality traits.

Mechanical testing of solid wood requires felling of trees. Further, the preparation of test specimens and the tests is timeconsuming and expensive. Wood density is commonly determined by the maximum moisture method, which is much faster and can be used with batches of samples (Smith 1954).

SilviScan is an instrument that provides detailed data on radial variations in a large number of wood and fiber traits, including density, MFA, and MOE (Evans 1994; Evans 2006). It is frequently used as a benchmark to estimate wood properties from increment cores (Vikram et al. 2011; Kennedy et al. 2013). It is much more efficient than traditional methods, but the sample preparation and measurements are too timeconsuming and expensive for scanning samples from the thousands of trees handled in the breeding programs (Wessels et al. 2011). NIR technique could also be applied if reliable prediction models could be developed (Schimleck et al. 2001; Schimleck and Evans 2004).

Several instruments have been developed to indirectly estimate wood density in standing tree without sample extraction or at least to rank the trees for breeding selection. Examples are the Pilodyn wood tester, the torsiometer, and the Resistograph, which have been proposed to replace the standard wood density method (Isik and Li 2003; Wessels et al. 2011). Pilodyn is commonly used to estimate the density of standing trees, and relatively high correlation between Pilodyn readings and wood density has been reported in several conifers (Cown 1978; Sprague et al. 1983; King 1988; Yanchuk and Kiss 1993; Fukatsu et al. 2011). Pilodyn can, however, only measure the wood density for the outermost annual rings (close to the bark), and therefore, it may be unreliable for ranking individual trees for wood density of the whole core or stem cross section (Wessels et al. 2011). Isik and $\mathrm{Li}$ (2003) proposed that Resistograph may be a more effective alternative as a tool to assess wood density in standing trees.

MFA is one of the most important wood properties in tree breeding, due to its influence on the mechanical properties
(Zobel and Jett 1995; Lindström et al. 2004), but it is also debatable how much it affects the properties of the mature wood (Cown et al. 1999). Direct measurement using microscopy on individual fiber is extremely time-consuming and expensive, and the representativity of the results is disputable unless a very large number of fibers are analyzed. It has been reported that acoustic velocity (AV) measured with Hitman ST 300 device could be an efficient indirect method for estimation MFA (Grabianowski et al. 2006; Li et al. 2007; Lenz et al. 2013).

MOE is the most important trait for construction timber. Much work has been devoted to the development of efficient nondestructive evaluation (NDE) methods to indirectly measure MOE. One approach is to estimate MOE acoustically by measuring the acoustic velocity, as MOE correlates with the product of squared sound velocity and green wood density according to the following equation.

$M O E_{D}=v^{2} * d$

where $M O E_{D}$ is the dynamic modulus of elasticity (GPa), $v$ is the acoustic velocity $\left(\mathrm{km} \mathrm{s}^{-1}\right)$, and $d$ is the green wood density $\left(\mathrm{kg} \mathrm{m}^{-3}\right)$. Such estimates of MOE are usually referred to as time-of-flight MOE (Bucur 2006).

The acoustic method has been developed for use on standing trees, for sorting of logs and for sawmill board grading. Several instruments have been developed for acoustic NDE (Carter et al. 2005; Wang et al. 2007; Wang 2013). Use of acoustic NDE has been well documented for assessing stiffness of boards from many species, such as Scots pine (Pinus sylvestris) (Auty and Achim 2008), Sitka spruce (Picea sitchensis) (Kennedy et al. 2013), Douglas-fir (Pseudotsuga menziesii), and loblolly pine (Pinus teada) (Shmulsky et al. 2006; Lachenbruch et al. 2010). Portable acoustic tools have been developed for standing trees, which have the advantage of being nondestructive and less time-consuming giving lower costs (Matheson et al. 2008).

According to the formula above, also wood density is required for predicting acoustic MOE from the standing tree. Since Pilodyn measurement is related to outerwood density (Cown 1978), the Pilodyn measurement could be used as a surrogate trait of wood density on estimating acoustic MOE, thereby combining two nondestructive measurements on the standing tree. This is an attractive option for predicting MOE of standing trees.

In this paper, we investigated the reliability of combining acoustic velocity with Pilodyn measurement for predicting acoustic MOE in Norway spruce using a large population and with SilviScan measurement of MOE on a sample from the same tree as the benchmark. The main objectives of this study were as follows: (1) to study whether two indirect and nondestructive measurements (Pilodyn penetration and 
acoustic velocity) on standing trees can be used as an effective NDE procedure to predict wood density, MFA, and MOE phenotypically and genetically, using SilviScan as a benchmark; (2) to estimate heritabilities of these indirect wood measurements; and (3) to evaluate the efficiency of selection based on these indirect wood measurements for benchmark objective traits including growth traits.

\section{Materials and methods}

Two large progeny trials, S21F9021146 aka F1146 (trial1) and S21F9021147 aka F1147 (trial 2), were established in 1990 in southern Sweden, with 1373 and 1375 open pollinated halfsib families, respectively. A randomized incomplete block design using single-tree plot was used in both trials. Detailed descriptions about field design, soil type, and climate condition were given in the previously published paper (Chen et al. 2014). The current study is based on a subset of 524 families. Diameter at breast height (DBH) was assessed at age 12 and $21\left(\mathrm{DBH}_{12}\right.$ and $\left.\mathrm{DBH}_{21}\right)$, and height was measured at age 7 $\left(\mathrm{Ht}_{7}\right)$ in both trials (Table 1).

\subsection{SilviScan data}

The details of sampling for increment cores, measurements of density, MFA, and MOE with SilviScan and calculations of area-weighted averages representing cross sections were shown in the paper (Chen et al. 2014). In the current work, area-weighted mean wood properties of density, MOE, and MFA for each increment cores were calculated based on all rings of the increment cores, $24 \%$ of the cores having 15 or less rings, $65 \%$ having $16-17$ rings, and about $11 \%$ having
18 to 19 rings. In Chen et al. (2014), however, all calculations were based on area-weighted averages for 15 rings for consistency and as the outermost rings are sometimes influenced by the sampling. This resulted in higher heritabilities of 0.52 , 0.23 , and 0.38 for wood density, MFA, and MOE, respectively. Our reason for including also the outermost rings in the current study was that the Pilodyn and Hitman measurements are performed from the outside of the stem.

\subsection{Measurement of Pilodyn penetration depth in standing} trees

Pilodyn penetration depth was measured in September 2011 at age $22\left(\right.$ Pilo $\left._{22}\right)$, using a Pilodyn 6J Forest (PROCEQ, Zurich, Switzerland) with a $2.0-\mathrm{mm}$ diameter pin, without removing bark. To keep consistence, Pilodyn measurement was made at approximate $1.3 \mathrm{~m}$ above the ground for each tree and on the same side for all trees.

\subsection{Measurement of acoustic velocity}

The Hitman ST300 tool (Fiber-gen, Christchurch; New Zealand) was used to determine acoustic velocity at age 24 $\left(\mathrm{AV}{ }_{24}\right)$, at the tree side with fewer branches. The branches of the trees below approximately $2 \mathrm{~m}$ were removed before the measurement. To avoid knots as much as possible, the upper probe was usually inserted just below the higher branch whorl and the lower probe was placed just above the lower whorl. All measurements were conducted within the consecutive 3 weeks from middle October and early November 2013. For each tree, 16 or 24 readings were made, and the average of the readings was used.

Table 1 Description of measured and calculated traits

\begin{tabular}{|c|c|c|}
\hline Abbreviation & Description of traits & Unit \\
\hline \multicolumn{3}{|c|}{ Indirect wood traits for predicting benchmark SilviScan traits } \\
\hline $\mathrm{AV}_{24}$ & Acoustic velocity measured by Hitman ST 300 at tree age 24 & $\mathrm{~km} \mathrm{~s}^{-1}$ \\
\hline $\mathrm{AV}_{24}^{2}$ & Square of acoustic velocity & $\left(\mathrm{km} \mathrm{s}^{-1}\right)^{2}$ \\
\hline $\mathrm{Pilo}_{22}$ & Pilodyn penetration depth measured by Pilodyn $6 \mathrm{~J}$ Forest at tree age 22 & $\mathrm{~mm}$ \\
\hline $\operatorname{MOE}_{\left(\mathrm{AV}^{2}+D\right)}$ & Modulus of elasticity estimated by acoustic velocity and SilviScan's wood density & $\mathrm{GPa}$ \\
\hline $\operatorname{MOE}_{\left(\mathrm{AV}^{2}+\mathrm{Pilo}\right)}$ & Modulus of elasticity estimated by acoustic velocity and Pilodyn penetration depth & $\mathrm{GPa}$ \\
\hline \multicolumn{3}{|c|}{ SiviScan benchmark wood traits } \\
\hline Density $_{21}$ & Wood density measured by SilviScan in increment cores at tree age 21 & $\mathrm{~kg} \mathrm{~m}^{-3}$ \\
\hline $\mathrm{MFA}_{21}$ & Microfibril angle measured by SilviScan in increment cores at tree age 21 & $\left({ }^{\circ}\right)$ \\
\hline $\mathrm{MOE}_{21}$ & Modulus of elasticity measured by SilviScan in increment cores at tree age 21 & $\mathrm{GPa}$ \\
\hline \multicolumn{3}{|l|}{ Growth traits } \\
\hline $\mathrm{DBH}_{\mathrm{x}}$ & Diameter at breast height at tree age 12 and 21 & $\mathrm{~mm}$ \\
\hline $\mathrm{Ht}_{7}$ & Tree height at tree age 7 & $\mathrm{~cm}$ \\
\hline
\end{tabular}




\subsection{Estimate of dynamic acoustic MOE}

In this study, Pilodyn data $\left(\mathrm{Pilo}_{22}\right)$ were used as surrogate for standing tree wood density data. Based on observed high correlation between Pilodyn penetration and wood density in one previous Norway spruce studies (Costa-e-Silva et al. 2000), the dynamic MOE was estimated using the following model:

$$
\operatorname{MOE}_{\left(\mathrm{AV}^{2}+\mathrm{Pilo}\right)}=(1 / \text { Pilo }) * 10,000 * \mathrm{AV}^{2}
$$

where Pilo is the Pilodyn penetration depth $(\mathrm{mm})\left(\mathrm{Pilo}_{22}\right)$ and $\mathrm{AV}$ is the velocity of the wave through the material $\left(\mathrm{km} \mathrm{s}^{-1}\right)$ $\left(\mathrm{AV}_{24}\right)$. The inverse of Pilo was used since it is inversely correlated with wood density, but a scale parameter of 10 , 000 was used to adjust its value to the same scale as wood density and consequently also the prediction of wood stiffness to the typical level of MOE of wood.

For comparison, the acoustic MOE has been estimated also with use of wood density from SilviScan as follows:

$M O E_{\left(A V^{2}+D\right)}=D * A V^{2}$

where $D$ is the area-weighted air-dry density (Density ${ }_{21}$ ) determined from the increment core sample $\left(\mathrm{kg} \mathrm{m}^{-3}\right)$ and $\mathrm{AV}$ is the velocity $\left(\mathrm{AV}_{24}\right)$ of the wave through the material $\left(\mathrm{km} \mathrm{s}^{-1}\right)$. In Norway spruce, the applicability of this equation has been verified in a previous study (Haines and Leban 1997).

\subsection{Statistical analyses}

Variance and covariance components for genetic analyses were estimated using ASREML3.0 (Gilmour et al. 2009), and the following linear mixed model for joint-site analysis was fitted as follows:

$Y_{i j k l m}=\mu+S_{i}+B_{j(i)}+P_{k}+S P_{i K}+F_{l(k)}+S F_{i l(k)}+e_{i j k l m}$

where $Y_{i j k l m}$ is the observation on the $m$ th tree from the $l$ th family within the $k$ th stand (plus tree selection stand) in the $j$ th block within the $i$ th site, $\mu$ is the general mean, $S_{i}, B_{j(i)}, P_{k}$, and $S P_{i K}$ are the fixed effects of the $i$ th site, the $j$ th block within the $i$ th site, and the $k$ th stand, the $i$ th site by the $k$ th stand interaction, respectively, $F_{l(k)}$ and $\mathrm{SF}_{i l(k)}$ are the random effects of the $l$ th family within the $k$ th stand and the random interactive effect of the $i$ th site and the $l$ th family within the $k$ th stand, respectively, and $e_{i j k l m}$ is the random residual effect. The effect will be dropped if it is not significant.

Estimates of heritability were obtained for each trait using variance components from the univariate joint-site analysis. Standard errors were estimated by using the Taylor series expansion method (Gilmour et al. 2009).
The individual-tree narrow-sense heritability for each trait was estimated by

$\widehat{\mathrm{h}}_{\mathrm{i}}^{2}=\frac{\widehat{\sigma}_{\mathrm{A}}^{2}}{\widehat{\widehat{\sigma}}_{\mathrm{p}}^{2}}=\frac{4 \times \widehat{\sigma}_{\mathrm{f}}^{2}}{\widehat{\sigma}_{\mathrm{f}}^{2}+\widehat{\sigma}_{\mathrm{fs}}^{2}+\widehat{\sigma}_{\mathrm{e}}^{2}}$

where $\hat{\mathrm{h}}_{\mathrm{i}}^{2}, \widehat{\sigma}_{\mathrm{A}}^{2}, \widehat{\sigma}_{\mathrm{f}}^{2}, \widehat{\sigma}_{\mathrm{fs}}^{2}, \widehat{\sigma}_{\mathrm{e}}^{2}$, and $\widehat{\sigma}_{\mathrm{p}}^{2}$ are the narrow-sense heritability and additive genetic, family within stand, family within stand by site, residual, and phenotypic variance components, respectively.

Phenotypic and genetic correlations between traits were calculated as

$r_{(x, y)}=\frac{\widehat{\sigma}_{(x, y)}}{\sqrt{\widehat{\sigma}_{(x)}^{2} \times \widehat{\sigma}_{(y)}^{2}}}$

where $\widehat{\sigma}_{(\mathrm{x})}^{2}$ and $\widehat{\sigma}_{(\mathrm{y})}^{2}$ are the estimated phenotypic or genetic variances for traits $x$ and $y$, respectively, $\widehat{\sigma}_{(\mathrm{x}, \mathrm{y})}$ is the estimated phenotypic or genetic covariance between traits $x$ and $y$.

Genetic gain $\left(G_{A}\right)$ was calculated using a selection intensity of $1 \%(i=2.67)$ :

$G_{A}=i \times C V_{p} \times h_{i}^{2}$

where $\mathrm{CV}_{\mathrm{p}}$ is the coefficient of variation of phenotypic effect (calculated as the phenotypic standard deviation divided by the mean of a specific trait) and $h_{i}^{2}$ is the individual heritability.

The efficiency of selection for one trait on another trait was estimated as

$E_{\text {ind }}=r_{A(x, y)} \times \frac{h_{x}}{h_{y}}$

where $r_{(x, y)}$ is the additive genetic correlation between trait $x$ on which selection is made (indirect) and trait $y$ on which the effect is evaluated (direct), and $h_{x}$ and $h_{y}$ are the square roots of individual-tree narrow-sense heritability of these two traits (White et al. 2007).

\section{Results}

3.1 Variation in wood quality and growth traits

Descriptive statistics for indirect wood measurement traits and SilviScan benchmark traits including growth traits are given in Table 2. The highest coefficients of variation (CVs), about $30 \%$, were observed for the phenotypes of DBH and height, while the CVs for phenotypes of wood quality traits (indirect 
Table 2 Descriptive statistics of growth traits, indirect wood traits measured in standing trees, and benchmark wood traits measured by SilviScan using increment cores at corresponding ages

\begin{tabular}{|c|c|c|c|c|c|c|c|c|}
\hline Trait & Min & Max & Mean & $\sigma_{a}$ & $\mathrm{CV}_{\mathrm{A}}(\%)$ & $\sigma_{p}$ & $\mathrm{CV}_{\mathrm{p}}(\%)$ & $\hat{h}_{i}^{2}(\mathrm{SE})$ \\
\hline \multicolumn{9}{|l|}{ Growth traits } \\
\hline $\mathrm{DBH}_{12}(\mathrm{~mm})$ & 1 & 146 & 57.7 & 8.91 & 15.45 & 18.24 & 31.62 & $0.24(0.02)$ \\
\hline $\mathrm{DBH}_{21}(\mathrm{~mm})$ & 9 & 264 & 102.8 & 12.25 & 11.91 & 28.88 & 28.10 & $0.18(0.02)$ \\
\hline $\mathrm{Ht}_{7}(\mathrm{~cm})$ & 5 & 480 & 222.4 & 33.21 & 14.93 & 65.04 & 29.25 & $0.26(0.02)$ \\
\hline \multicolumn{9}{|l|}{ Indirect wood traits } \\
\hline $\mathrm{AV}_{24}\left(\mathrm{~km} \mathrm{~s}^{-1}\right)$ & 2.99 & 5.01 & 4.18 & 0.11 & 2.52 & 0.27 & 6.57 & $0.15(0.05)$ \\
\hline $\mathrm{AV}_{24}^{2}\left(\mathrm{~km} \mathrm{~s}^{-1}\right)^{2}$ & 8.93 & 25.05 & 17.54 & 0.88 & 5.04 & 2.27 & 12.95 & $0.15(0.05)$ \\
\hline $\mathrm{Pilo}_{22}(\mathrm{~mm})$ & 10 & 34 & 21.4 & 1.49 & 6.97 & 2.55 & 11.93 & $0.34(0.05)$ \\
\hline $\operatorname{MOE}_{\left(\mathrm{AV}^{2}+\mathrm{D}\right)}(\mathrm{GPa})$ & 3.27 & 14.61 & 7.57 & 0.74 & 9.72 & 1.32 & 17.41 & $0.31(0.06)$ \\
\hline $\operatorname{MOE}_{\left(\mathrm{AV}^{2}+\mathrm{Pilo}\right)}(\mathrm{GPa})$ & 3.15 & 16.71 & 8.35 & 0.80 & 9.63 & 1.53 & 18.32 & $0.28(0.05)$ \\
\hline \multicolumn{9}{|c|}{ Benchmark SilviScan wood traits } \\
\hline Density $_{21}\left(\mathrm{~kg} \cdot \mathrm{m}^{-3}\right)$ & 298.2 & 676.5 & 429.8 & 26.26 & 6.11 & 37.24 & 8.67 & $0.50(0.06)$ \\
\hline $\mathrm{MFA}_{21}\left({ }^{\circ}\right)$ & 4.60 & 32.83 & 14.16 & 1.65 & 11.63 & 4.28 & 30.24 & $0.15(0.04)$ \\
\hline $\mathrm{MOE}_{21}(\mathrm{GPa})$ & 5.08 & 20.69 & 12.28 & 1.21 & 9.89 & 2.12 & 17.27 & $0.33(0.05)$ \\
\hline
\end{tabular}

Standard errors are given in parenthesis

and benchmark SilviScan traits) were less than $20 \%$ (6.6 to $18.3 \%$ ) except for $\mathrm{MFA}_{21}$ that showed a CV of $30.2 \%$. The $\mathrm{CV}$ for additive effect was about half of $\mathrm{CV}$ for phenotype effect for all the traits.

The minimum, maximum, mean, genetic, and phenotypic variation and coefficient for both genotypes and phenotypes were similar between the predictions of acoustic MOEs using SilviScan wood density, $\operatorname{MOE}_{\left(A V^{2}+D\right)}$, and using Pilodyn measurement, $\mathrm{MOE}_{\left(A V^{2}+P i l o\right)}$ (Table 2).

3.2 Phenotypic and genetic correlation between indirect wood measurements (Pilodyn measurement, acoustic velocity, acoustic MOE) and SilviScan benchmark density, MFA, and $\mathrm{MOE}$

The accuracies of the predictions of benchmark SilviScan traits using indirect wood traits were evaluated using phenotypic and genetic correlations (Table 3). Both $\mathrm{AV}_{24}$ and $\mathrm{AV}_{24}^{2}$ had the same moderate phenotypic correlations with $\mathrm{MFA}_{21}$ $(-0.40)$ but lower phenotypic correlation with Density ${ }_{21}$ $(0.29)$ as might be expected. In contrast, Pilo $_{22}$ had much higher phenotypic correlation with Density ${ }_{21}(-0.62)$ but low correlation with $\mathrm{MFA}_{21}(-0.09)$ as expected. The combination of $\mathrm{AV}_{24}^{2}$ and $\mathrm{Pilo}_{22}$ had slightly higher phenotypic correlation (0.53) with benchmark $\mathrm{MOE}_{21}$ than with $\mathrm{AV}^{2}{ }_{24}$ alone $(0.50)$ but significantly higher correlation than with Pilo $_{22}(-0.26)$ alone. The phenotypic correlations are thus moderate between Pilo $_{22}$ and Density 21 , and between $\mathrm{AV}_{24}$ and $\mathrm{MFA}_{21}$, and they are low between Pilo $_{22}$ and MFA ${ }_{21}$, and between $\mathrm{AV}_{24}$ and Density 21 .
The genetic correlations were much higher than the phenotypic ones. Both $\mathrm{AV}_{24}$ and $\mathrm{AV}_{24}^{2}$ had very high genetic correlation with $\mathrm{MFA}_{21}$ ( -0.94 and -0.93 , respectively) but moderate genetic correlation with Density 21 ( 0.47 for both $\mathrm{AV}_{24}$ and $\left.\mathrm{AV}_{24}^{2}\right)$. Pilo 22 had very high genetic correlation with Density $_{21}(-0.96)$ but lower genetic correlation with $\mathrm{MFA}_{21}$ (0.30). The $R^{2}$ values for the corresponding relationships at individual breeding value level estimated with bivariate models also showed similar values (Fig. 1). For example, $R^{2}$ was 0.99 between Density $_{21}$ and Pilo 22 , and 0.98 between $\mathrm{MFA}_{21}$ and $\mathrm{AV}_{24}$. The combination of $\mathrm{AV}_{24}^{2}$ and $\mathrm{Pilo}_{22}$ had almost a perfect genetic correlation with benchmark $\mathrm{MOE}_{21}$ (0.99) (Fig. 2) but somewhat lower genetic correlation with $\mathrm{AV}_{24}^{2}$ alone (0.89) and Pilo 22 alone $(-0.77)$.

Growth traits showed negative genetic correlations with Density $_{21}$ and $\mathrm{MOE}_{21}$, and positive correlations with Pilo $_{22}$ and $\mathrm{MFA}_{21}$.

3.3 Heritability of indirect wood traits including growth traits

Heritability varied from 0.15 for acoustic velocity $\left(\mathrm{AV}_{24}\right.$ and $\mathrm{AV}_{24}^{2}$ ) to 0.34 for $\mathrm{Pilo}_{22}$. Heritabilities for acoustic MOE were similar (0.28 for $\mathrm{MOE}_{\left(A V^{2}+\text { Pilo }\right)}$ and 0.31 for $\left.\mathrm{MOE}_{\left(A V^{2}+D\right)}\right)$. These two heritabilities were also similar to the heritability of the benchmark $\mathrm{MOE}_{21}(0.33)$. This may also be compared to the heritability of 0.38 obtained for benchmark MOE based on annual rings 1-15 (Chen et al. 2014), indicating that calculation with data of the same age for all trees and exclusion of rings where data may have been influenced by sampling provides higher heritability. A similar pattern was observed for MFA. The heritability for benchmark MFA ${ }_{21}$ was the same as 


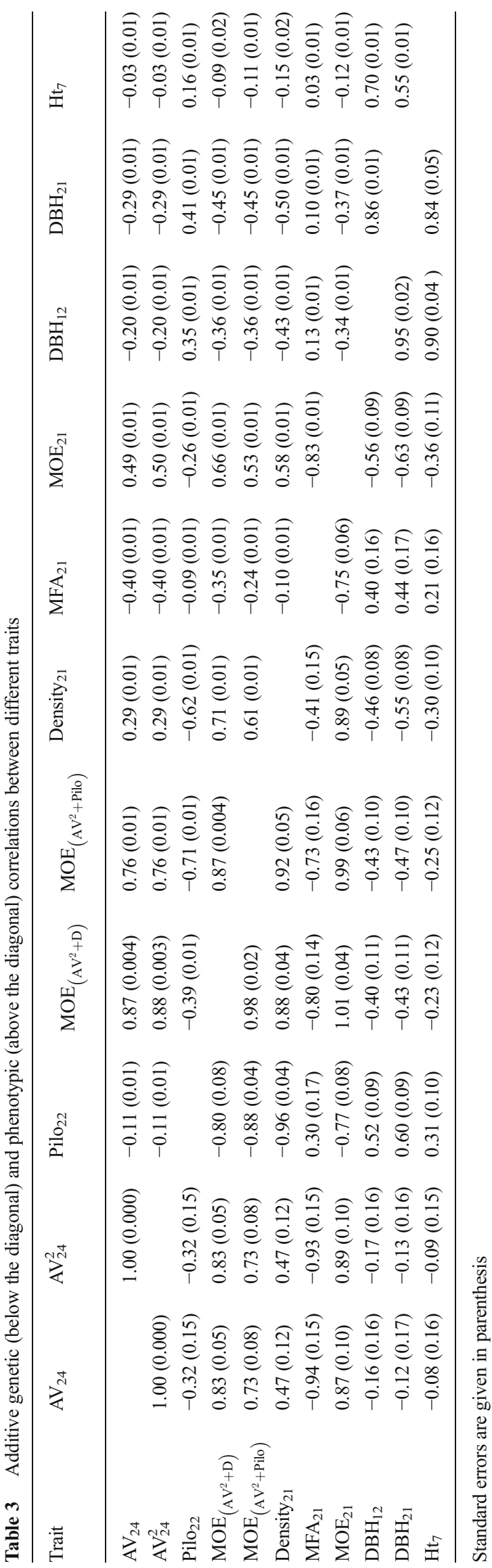

for acoustic velocity (0.15) using all rings but higher for MFA when calculated from rings 1 to 15 only $(0.23)$. Heritability for $\mathrm{Pilo}_{22}$ was higher (0.34), but not as high as for the benchmark Density $_{21}$ (0.50) (0.52 for ring 1-15 only). Heritability for $\mathrm{DBH}_{12}(0.24)$ was higher than the $\mathrm{DBH}_{21}(0.18)$, and $\mathrm{Ht}_{7}$ heritability was similar to $\mathrm{DBH}_{12}(0.26)$.

3.4 Selection efficiency based on direct and indirect measure of wood quality traits

The efficiency of direct and indirect selection is presented in Table 4 , assuming a selection intensity of $1 \%$. Genetic gains larger than $10 \%$ were observed for most traits except for two velocity traits $\left(\mathrm{AV}_{24}\right.$ and $\left.\mathrm{AV}_{24}^{2}\right)$ for direct selection. For growth traits, $\mathrm{Ht}_{7}$ and $\mathrm{DBH}_{12}$ showed the largest genetic gains (20.32 and $20.12 \%$, respectively). Genetic gains for $\mathrm{Pilo}_{22}, \mathrm{AV}_{24}^{2}$, $\operatorname{MOE}_{\left(A V^{2}+D\right)}$, and $\mathrm{MOE}_{\left(\mathrm{AV}^{2}+\text { Pilo }\right)}$ were $10.85,5.23,14.45$, and $13.46 \%$, respectively. For the benchmark wood traits, Density $_{21}, \mathrm{MFA}_{21}$, and $\mathrm{MOE}_{21}$, they were $11.48,11.93$, and $15.08 \%$, respectively, thus higher than the indirect traits for MFA but only slightly higher than the indirect traits of $\mathrm{Pilo}_{22}$ and $\mathrm{MOE}_{\left(\mathrm{AV}^{2}+\text { Pilo }\right)}$.

The efficiency of indirect selection using indirect wood traits for benchmark wood traits is shown in Table 4. Selection on both $\mathrm{AV}_{24}$ and $\mathrm{AV}_{24}^{2}$ had similar efficiencies ( -0.93 and -0.94 , respectively) for benchmark trait $\mathrm{MFA}_{21}$. Selection for $\mathrm{MFA}_{21}$ based on $\mathrm{MOE}_{\left(\mathrm{AV}^{2}+\mathrm{D}\right)}$ and $\mathrm{MOE}_{\left(\mathrm{AV}^{2}+\mathrm{Pilo}\right)}$ showed even higher efficiency (1.16 and 1.00 , respectively). Indirect selection was found very efficient for $\mathrm{MFA}_{21}$ as long as velocity was included. But, selection based on acoustic velocity was not efficient for wood density, as expected, and not for growth traits in this study. Selection based on Pilo $_{22}$ had high efficiency on benchmark wood density $($ Density 21$)(0.80)$ and for $\mathrm{DBH}_{21}(0.82)$. Indirect selection based on $\mathrm{MOE}_{\left(\mathrm{AV}^{2}+\mathrm{D}\right)}$ and $\mathrm{MOE}_{\left(\mathrm{AV}^{2}+\text { Pilo }\right)}$ was observed highly effective for benchmark $\mathrm{MOE}_{21}$, with efficiency of 0.98 and 0.92 , respectively.

\section{Discussion}

4.1 Predictability of wood density, MFA, and MOE using Pilodyn penetration and acoustic velocity

The importance of wood quality has been recognized for a long time and is well documented (Dadswell et al. 1961; Zobel and Van Buijtenen 1989). However, the incorporation of wood quality traits into selective conifer tree breeding only occurred recently (Isik and Li 2003; Hannrup et al. 2004; Li et al. 2007; Wu et al. 2007). The three reasons for such delay 
Fig. 1 Relationships between a Pilodyn measurement $\left(\mathrm{Pilo}_{22}\right)$ and Density $_{21}$, b Pilo $_{22}$ and $\mathrm{MFA}_{21}$, c acoustic velocity $\left(\mathrm{AV}_{24}\right)$ and Density $_{21}$, and $\mathbf{d} \mathrm{AV}_{24}$ and $\mathrm{MFA}_{21}$ at individual breeding value level

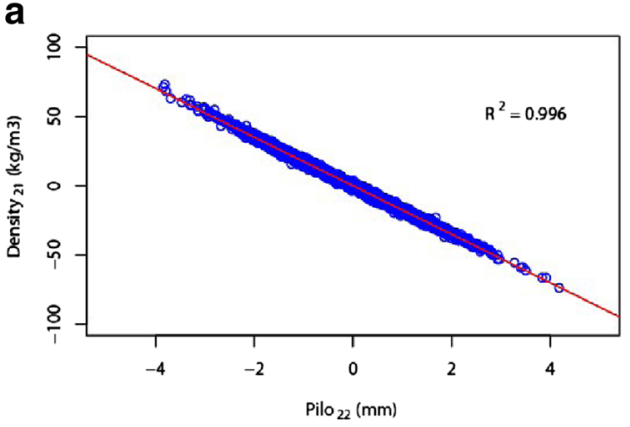

b

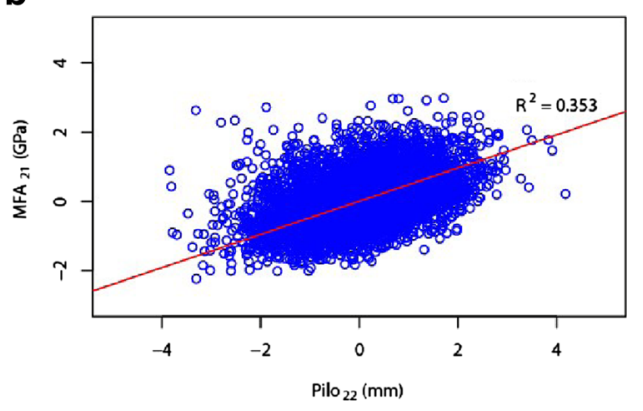

C

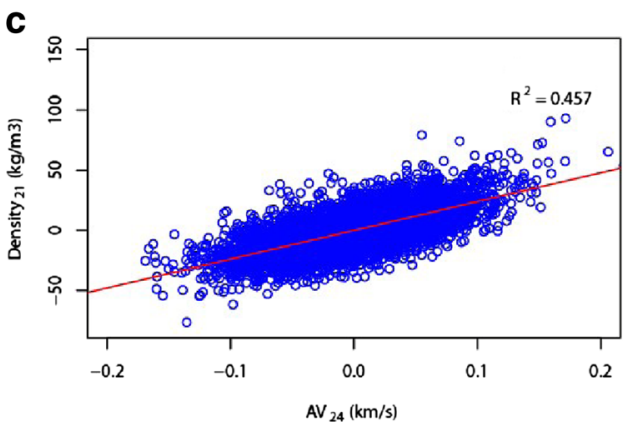

d

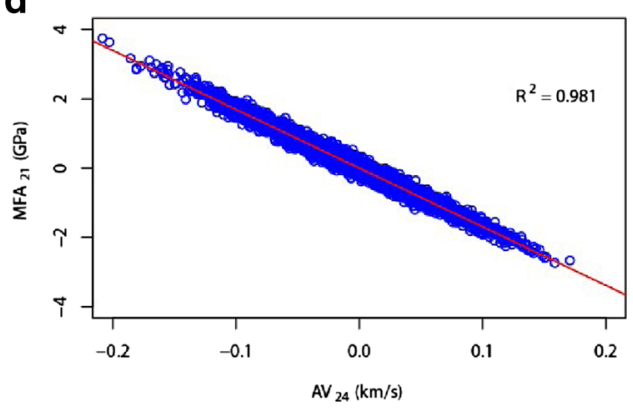

are usually cited as follows: (1) Measuring large numbers of trees for wood quality traits (wood density and MOE) is timeconsuming and expensive, (2) there is no market push (premium) for high wood density and MOE in mill door, and (3) most advanced-generation breeding programs of conifer did not start until 1980s, and breeding objectives were not well-defined for the first two generations. The issue of declined wood quality was first recognized in radiata pine due to early success of breeding in increasing volume (Cown 1992; Wu et al. 2007; Burdon et al. 2008). A particular concern was the negative genetic correlation between growth and wood stiffness (MOE). Large projects for improving wood quality, such as High Wood Density breeds (Jayawickrama and Carson 2000) and Juvenile Wood Initiative, were initiated for improving wood quality in radiata

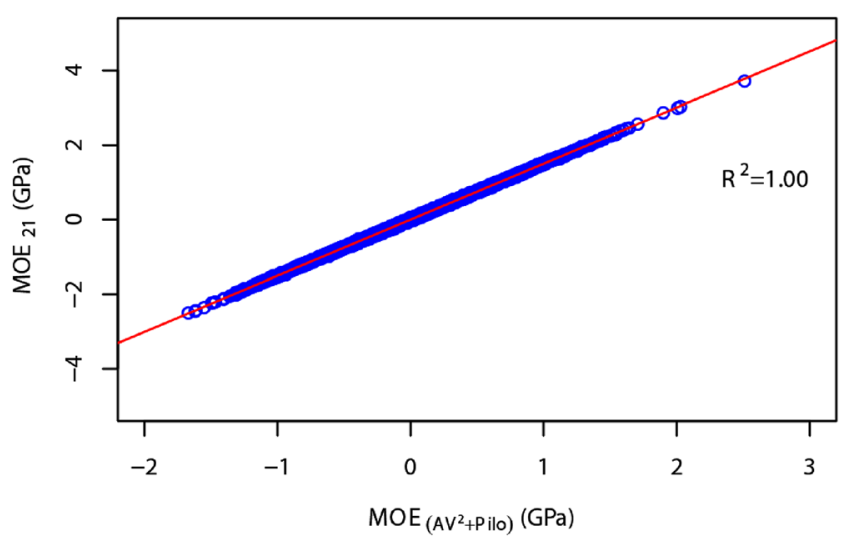

Fig. 2 Relationship between $\mathrm{MOE}_{21}$ and $\mathrm{MOE}_{\left(\mathrm{AV}^{2}+\mathrm{Pilo}\right)}$ at individual breeding value level pine breeding (Wu et al. 2007) and other species in the third breeding generation.

One issue associated to breeding for wood quality, particularly for structural wood products, is the requirement to screen several thousand or tens of thousands of trees for selection. Earlier attempts using Pilodyn as a surrogate trait for wood density were partially successful (Sprague et al. 1983; Wessels et al. 2011). Inconsistence of measurements due to different operators or different tree ages and shallow penetration on outer growth rings has limited the use of Pilodyn (Wessels et al. 2011). The introduction of the Resistograph overcame some shortages of Pilodyn (Isik and Li 2003) in the estimation of wood density. The most important trait for structural wood products is, however, wood stiffness. It can be measured with SilviScan, which also delivers data on wood density and MFA, but it is costly. Development and wide spread use of acoustic tools in log segregation and sawmill application have enhanced the use of such tool to measure stiffness in standing trees (Wang et al. 2007). However, prediction of MOE from acoustic tools needs to be complemented with information on wood density (green or dry). Especially in older stands, the impact of MFA might be less than density. An example is the strong variation of wood density and wood stiffness among site but little evidence of variation in MFA (Moore et al. 2014). Therefore, a combined use of Pilodyn and acoustic measurement would be an ideal method to predict MOE in standing trees.

Our study showed that Pilodyn data had a genetic correlation with wood density as high as -0.96 correlation and acoustic velocity with MFA on the same level: -0.94 . This supported our thinking to combine these two destructive traits for 
Table 4 Efficiency of indirect selection on growth and wood quality traits

the value in parenthesis represents genetic gain of direct selection for benchmark traits under selection intensity of $1 \%(i=2.67)$

\begin{tabular}{llllll}
\hline Benchmark traits & \multicolumn{5}{l}{ Indirect traits } \\
\cline { 2 - 6 } & $\begin{array}{l}\mathrm{AV}_{24} \\
(2.57 \%)\end{array}$ & $\begin{array}{l}\mathrm{AV}_{24}^{2} \\
(5.23 \%)\end{array}$ & $\begin{array}{l}\mathrm{Pilo}_{22} \\
(10.85 \%)\end{array}$ & $\begin{array}{l}\mathrm{MOE}_{\left(\mathrm{AV}^{2}+\mathrm{D}\right)} \\
(14.45 \%)\end{array}$ & $\begin{array}{l}\mathrm{MOE}_{\left(\mathrm{AV}^{2}+\mathrm{Pil}\right)} \\
(13.46 \%)\end{array}$ \\
\hline Density $_{21}(11.48 \%)$ & 0.26 & 0.26 & -0.80 & 0.69 & 0.68 \\
$\mathrm{MFA}_{21}(11.93 \%)$ & -0.93 & -0.94 & 0.46 & -1.16 & -1.00 \\
$\mathrm{MOE}_{21}(15.08 \%)$ & 0.58 & 0.60 & -0.78 & 0.98 & 0.92 \\
$\mathrm{DBH}_{12}(20.12 \%)$ & -0.13 & -0.14 & 0.62 & -0.46 & -0.46 \\
$\mathrm{DBH}_{21}(13.46 \%)$ & -0.11 & -0.12 & 0.82 & -0.57 & -0.58 \\
$\mathrm{Ht}_{7}(20.32 \%)$ & -0.06 & -0.07 & 0.35 & -0.25 & -0.26 \\
\hline
\end{tabular}

predicting MOE on standing trees. We found that the combination of Pilodyn and acoustic velocity had a genetic correlation of 0.99 . This indicates that tree breeders can reliably select high stiffness Norway spruce trees for breeding purpose using the two nondestructive methods (Pilodyn penetration and acoustic velocity) on standing trees. Moderate or high genetic correlations between MOE and acoustic velocity have also been reported in other conifers (Auty and Achim 2008; Kennedy et al. 2013; Lenz et al. 2013).

The phenotypic correlations were -0.62 for wood density, -0.40 for MFA, and 0.53 for MOE, which are on the low side for predictions of these properties on individual trees, but may be useful on sorting for enrichment of materials with desired properties.

High genetic correlation between Pilodyn and wood density renders indirect selection for wood density with $80 \%$ selection efficiency when selection is based on Pilodyn measurement alone. This indicates that Pilodyn measurement can be considered as an effective indirect trait to evaluate genetic parameters of wood density in Norway spruce juvenile wood. Similar results have been reported before (Cown 1978; Greaves et al. 1996; Costa-e-Silva et al. 2000; Wessels et al. 2011). Similarly, comparable heritability between acoustic velocity and MFA along with a high genetic correlation resulted in a high selection efficiency of 93-94\% for MFA based on velocity. Strong genetic correlation between acoustic velocity and MFA was also found in another study (Kennedy et al. 2013).

The most interesting result is that the successful combination of Pilodyn penetration with acoustic velocity, based on the application of equation (1) with the inverse of Pilodyn penetration as surrogate for wood density, produced a selection efficiency for the benchmark MOE as high as $92 \%$, as compared to $58-60 \%$ using acoustic velocity alone and $78 \%$ using Pilodyn measurement alone.

\subsection{Genetic variation and heritability}

The coefficient of genetic variation $\left(\mathrm{CV}_{\mathrm{A}}\right)$ for growth traits was larger than the ones for wood quality traits, indicating that growth traits have more potential to improve in the breeding programs. However, due to the importance of wood mechanical properties for structural wood (Zobel and Jett 1995), even a small improvement in these traits is expected to result in substantial revenue. Therefore, both growth traits and wood quality traits are important for improvement with genetic and economic gain when implemented in forestry.

The estimated $\mathrm{CV}_{\mathrm{A}}$ for Pilodyn penetration is similar to values previously reported in Norway spruce (Costa-e-Silva et al. 2000; Hallingbäck et al. 2010). Similarly, the heritability of Pilodyn measurement agrees with the estimates reported in a previous study where it ranged from 0.30 to 0.62 (Costa-eSilva et al. 2000). However, a relative lower heritability $\left(h^{2}=\right.$ 0.27) was reported by Hallingbäk et al. (2010). In our study, heritability of SilviScan wood density was moderate $\left(h_{i}^{2}=0.50\right.$ and 0.52 based on rings $1-15$ ), indicating that density was strongly heritable. In Sitka spruce, the heritabilities of wood density and Pilodyn were reported to be higher than in our study (Kennedy et al. 2013). In their study, the heritability of Pilodyn was reported to be higher than density, possible due to multiple Pilodyn reading that could have improved the accuracy of the heritability estimate (Greaves et al. 1996). In our case, however, one shot for each tree may not be enough to smooth the measurement error, therefore resulting in a lower heritability as compared to the wood density measured by SilviScan. The other measurement error may result from different individual of operating Pilodyn and variation of bark thickness.

In this study, the $\mathrm{CV}_{\mathrm{A}}$ of acoustic MOE was similar to benchmark MOE calculated on data from all rings but lower than the benchmark as estimated excluding the outermost rings (>ring 15) (Chen et al. 2014). The heritabilities of the acoustic MOE (0.28-0.31) were slightly lower than those of the benchmark MOE calculated on all rings (0.33), which was however lower than the benchmark MOE for rings 1-15 (0.38). The value for the indirect selection efficiency would become even better if we could improve the estimated heritability for the acoustic MOE, for example by using multiple measurements of Pilodyn and acoustic velocity on the same tree, which would also improve the selection efficiency itself. 


\section{Conclusion}

The results from this study indicate that

1. Acoustic velocity on standing trees can provide high selection efficiency for MFA in Norway spruce.

2. Pilodyn penetration on stems can provide high selection efficiency for wood density in Norway spruce.

3 . The combination of acoustic velocity and Pilodyn penetration on stand trees can be used for efficient indirect selection for MOE in Norway spruce.

Acknowledgments The funding for the measurements with Pilodyn and Hitman was provided by the Swedish Association for Forest Tree Breeding (Föreningen Skogsträdsförädling). The samples for the acquisition of the direct traits were collected in Skogforsk's operative breeding experiments and managed by Johan Malm and other technical staff with funding from the Swedish Spruce Genome Sequencing project. The SilviScan measurements were performed at Innventia within the strategic research program Bio4Energy, funded by the Swedish government, where the samples were prepared and analyzed by Åke Hansson, Thomas Trost, and other researchers, and Thomas Grahn organized the data in the Bio4Energy Trait Database for the later steps of the evaluation.

\section{References}

Auty D, Achim A (2008) The relationship between standing tree acoustic assessment and timber quality in Scots pine and the practical implications for assessing timber quality from naturally regenerated stands. Forestry 81:475-487. doi:10.1093/forestry/cpn015

Burdon R, Carson M, Shelbourne C (2008) Achievements in forest tree genetic improvement in Australia and New Zealand 10: Pinus radiata in New Zealand. Aust For 71:263-279

Bucur V (2006) Acoustics of wood, 2nd ed. Springer Series in Wood Science Springer, Berlin, Heidelberg, Germany

Carter P, Briggs D, Ross RJ, Wang X (2005) Acoustic testing to enhance western forest values and meet customer wood quality needs. CA Harrington, SH Schoenholtz (Eds), Productivity of western forests: a forest products focus General Technical Report, PNW-GTR-642, USDA, Forest Service, Pacific Northwest Research Station, Portland, OR:121-129

Chen Z-Q, Gil MRG, Karlsson B, Lundqvist S-O, Olsson L, Wu HX (2014) Inheritance of growth and solid wood quality traits in a large Norway spruce population tested at two locations in southern Sweden. Tree Gene Genom:1-13. doi: 10.1007/s11295-014-0761-x

Costa-e-Silva J, Silva J, Borralho N, Wellendorf H (2000) Genetic parameter estimates for diameter growth, pilodyn penetration and spiral grain in Picea abies (L.) Karst. Silvae Genet 49:29

Cown D (1978) Comparison of the pilodyn and torsiometer methods for the rapid assessment of wood density in living trees. N Z J For Sci 8: 384-391

Cown D (1992) Corewood (juvenile wood) in Pinus radiata-should we be concerned? N Z J For Sci 22:87-95

Cown D, Hebert J, Ball R (1999) Modelling Pinus radiata lumber characteristics. Part 1: mechanical properties of small clears. N Z J For Sci 29:203-213

Dadswell H, Fielding J, Nicholls J, Brown A (1961) Tree to tree variations and the gross heritability of wood characteristics of Pinus radiata. TAPPI 44:174-179
Evans R (1994) Rapid measurement of the transverse dimensions of tracheids in radial wood sections from Pinus radiata. Holzforschung 48:168-172. doi:10.1515/hfsg.1994.48.2.168

Evans R (2006) Wood stiffness by X-ray diffractometry. In: Stokke DD, Groom HL (eds) Characterization of the cellulosic cell wall. Wiley, Hoboken, pp 138-146

Fukatsu E, Tamura A, Takahashi M, Fukuda Y, Nakada R, Kubota M, Kurinobu S (2011) Efficiency of the indirect selection and the evaluation of the genotype by environment interaction using Pilodyn for the genetic improvement of wood density in Cryptomeria japonica. J For Res 16:128-135

Gilmour AR, Gogel B, Cullis B, Thompson R (2009) ASReml user guide release 3.0. VSN International Ltd, Hemel Hempstead, UK

Grabianowski M, Manley B, Walker JCF (2006) Acoustic measurements on standing trees, logs and green lumber. Wood Sci Technol 40:205216. doi:10.1007/s00226-005-0038-5

Greaves BL, Borralho NMG, Raymond CA, Farrington A (1996) Use of a Pilodyn for the indirect selection of basic density in Eucalyptus nitens. Can J For Res 26:1643-1650. doi:10.1139/x26-185

Haines DW, Leban J-M (1997) Evaluation of the MOE of Norway spruce by the resonance flexure method. For Prod J 47:91-93

Hallingbäck HR, Jansson G, Hannrup B (2010) Genetic correlations between spiral grain and growth and quality traits in Picea abies. Can J For Res 40:173-183. doi:10.1139/x09-173

Hannrup B, Cahalan C, Chantre G, Grabner M, Karlsson B, Bayon IL, Jones GL, Müller U, Pereira H, Rodrigues JC, Rosner S, Rozenberg P, Wilhelmsson L, Wimmer R (2004) Genetic parameters of growth and wood quality traits in Picea abies. Scand J For Res 19:14-29. doi:10.1080/02827580310019536

Isik F, Li BL (2003) Rapid assessment of wood density of live trees using the Resistograph for selection in tree improvement programs. Can J For Res 33:2426-2435. doi:10.1139/X03-176

Ivković M, Wu HX, McRae TA, Powell MB (2006) Developing breeding objectives for radiata pine structural wood production. I. Bioeconomic model and economic weights. Can J For Res 36: 2920-2931

Jayawickrama K, Carson M (2000) A breeding strategy for the New Zealand radiata pine breeding cooperative. Silvae Genet 49:82-89

Kennedy SG, Cameron AD, Lee SJ (2013) Genetic relationships between wood quality traits and diameter growth of juvenile core wood in Sitka spruce. Can J For Res 43:1-6. doi:10.1139/cjfr-2012-0308

King J (1988) Selection of wood density and diameter in controlled crosses. Silvae Genet 37:3-4

Lachenbruch B, Johnson GR, Downes GM, Evans R (2010) Relationships of density, microfibril angle, and sound velocity with stiffness and strength in mature wood of Douglas-fir. Can J For Res 40:55-64. doi:10.1139/x09-174

Lenz P, Auty D, Achim A, Beaulieu J, Mackay J (2013) Genetic improvement of white spruce mechanical wood traits - early screening by means of acoustic velocity. Forests 4:575-594

Li X, Huber DA, Powell GL, White TL, Peter GF (2007) Breeding for improved growth and juvenile corewood stiffness in slash pine. Can J For Res 37:1886-1893. doi:10.1139/x07-043

Lindström H, Harris P, Sorensson CT, Evans R (2004) Stiffness and wood variation of 3-year old Pinus radiata clones. Wood Sci Technol 38: 579-597. doi:10.1007/s00226-004-0249-1

Matheson A, Gapare W, Ilic J, Wu H (2008) Inheritance and genetic gain in wood stiffness in radiata pine assessed acoustically in young standing trees. Silvae Genet 57:56-64

Moore J, Cown D, McKinley R (2014) Modelling microfibril angle variation in New Zealand-grown radiata pine. N Z J For Sci 44:1-11. doi:10.1186/s40490-014-0025-4

Schimleck LR, Evans R (2004) Estimation of Pinus radiata D. Don tracheid morphological characteristics by near infrared spectroscopy. Holzforschung 58:66-73 
508

Z.-Q. Chen et al.

Schimleck LR, Evans R, Ilic J (2001) Estimation of Eucalyptus delegatensis wood properties by near infrared spectroscopy. Can J For Res 31:1671-1675. doi:10.1139/x01-101

Shmulsky R, Shale RD, Snow RD (2006) Analysis of acoustic velocity as a predictor of stiffness and strength in 5-inch-diameter pine dowels. For Prod J 56:53-55

Smith DM (1954) Maximum moisture content method for determining specific gravity of small wood samples. Report 2014, Forest Products Laboratory, Forest Service, US Department of Agriculture Sprague JR, Talbert JT, Jett JB, Bryant RL (1983) Utility of the Pilodyn in selection for mature wood specific gravity in loblolly pine. For Sci 29:696-701

Vikram V, Cherry ML, Briggs D, Cress DW, Evans R, Howe GT (2011) Stiffness of Douglas-fir lumber: effects of wood properties and gemetics. Can J For Res 41:1160-1173. doi:10.1139/x11-039

Wang X (2013) Acoustic measurements on trees and logs: a review and analysis. Wood Sci Techno 47:965-975. doi:10.1007/s00226-0130552-9

Wang X, Carter P, Ross RJ, Bashaw BK (2007) Acoustic assessment of wood quality of raw forest materials: a path to increased profitability
Wessels CB, Malian FS, Rypstra T (2011) A review of measurement methods used on standing trees for the prediction of some mechancal properties of timber. Eur J For Res 130:881-893. doi:10.1007/ s10342-011-0484-6

White TL, Adams WT, Neale DB (2007) Forest genetics. CABI, Wallingford

Wu HX, Eldridge KG, Matheson AC, Powell MB, McRae TA, Butcher TB, Johnson IG (2007) Achievements in forest tree improvement in Australia and New Zealand: 8. Successful introduction and breeding of radiate pine in Australia. Aust For 70:215-225

Wu HX, Ivković M, Gapare WJ, Baltunis BS, Powell MB, McRae TA (2008) Breeding for wood quality and profit in radiate pine: a review of genetic parameters. N Z J For Sci 38:56-87

Yanchuk A, Kiss G (1993) Genetic variation in growth and wood specific gravity and its utility in the improvement of interior spruce in British Columbia. Silva Genet 42:141-141

Zobel BJ, Jett JB (1995) Genetics of wood production. Springer-Verlag, Berlin

Zobel BJ, Van Buijtenen JP (1989) Wood variation: its causes and controll. Springer-Verlag, Berlin

Springer

INA

science e IMPACI 